\title{
Using Dogme in ELT to develop student teachers' Speaking skills and their self-efficacy \\ By
}

Heba M. Mohamed, PhD

Associate professor of TEFL

Faculty of Education

Beni Suef University

\section{ABSTRACT}

The main purpose of this research is to determine the effectiveness of dogme in developing the student teachers' speaking skills as well as their speaking self- efficacy. Two statistical hypotheses were set to guide this research. The research adopted the one group research design to examine the study hypotheses. The participants consisted of $(\mathrm{N}=44)$ freshmen students English majors at the faculty of education in Beni Suef. The instruments and materials of the study represent in a pre-post speaking test, and a speaking self-efficacy scale, a checklist of speaking skills, a speaking rubric and ELT dogme. The research results revealed that dogme ELT has an impact on enhancing students' speaking skills as well as their speaking self-efficacy. This research has implications both for researchers conducting classroom-research and language teachers.

\section{Key words: Dogme-speaking skills - self-efficacy-speaking self- efficacy \\ Introduction}

English is used by millions of people for communicative purposes all over the world. Currently, English is also considered as a predominant and acceptable tool for global communication. Communication is the process of exchanging information among individuals, groups, institutions, and/or organizations in oral, written, or signed forms through any available media(Natale \& Lubniewski,,2018,p. 377). English as a second language (ESL) or English as a foreign language (EFL) is taught in all Arab countries to graduate students and individuals with good competence of English skills to help them communicate in their societies and European countries as well, (Hamad, 2013, p. 87).

Along with this, the teaching of speaking skill has become increasingly important in English as a second or foreign language (ESL/EFL) context due to the large number of students who want to study English in order to be able to use English for communicative purposes ( Iman, 2017,p. 88).It becomes more vital when it is known that "a large percentage of the world's language learners study English in order to develop proficiency in speaking" (Richards \& Renandya, 2002,p.201). Hence, at the age of communication, speaking seems to be playing a major role, and the purpose of teaching the English language has shifted 
Using Dogme in ELT to develop student teachers' Speaking skills and their

self-efficacy

from the mastery of structure to the ability to use the language for communicative reasons. (Soureshjani, 2013,p.167).

In the teaching of speaking skills, students are encouraged to be able to communicate verbally with fellow students (Litualy, 2016,p. 56). Speaking is a complex process that enables constructing a message in a form that other people can comprehend, and receive the message using the correct pronunciation, stress and intonation. Speaking also involves the interaction and communicating with other people. At the same time, learners need to be accurate and fluent enough for the other person to understand and to fit into the flow of conversation. To be able to do all of these, learners need lots and lots of practice, encouragement, and corrections (Lindsay \& Knight, 2006, p.68).

Consistent with this view, Nunan (2003) stated that teaching speaking means to teach language learners to:

-Utter the English speech sounds and sound patterns.

-Use word and sentence intonation, stress patterns and the rhythm .

-Choose suitable words and sentences according to the social setting, audience, situation and subject matter.

-Organize their thoughts in a comprehensible and logical sequence.

-Use language as tool of expressing values and judgments.

-Use the language confidently and quickly with few unnatural pauses, which is called as fluency.

Generally, five components of speaking skill are recognized in analyses of the speech process as follows:

1- Pronunciation: It refers to the way for students to produce the utterance of words clearly when they are speaking (Kline, 1998,p. 69).

2- Grammar: It is the formal study of the structure of a language and describes how words fit together in meaningful constructions (Williams, 2008,p.2).

3- Vocabulary: It can be defined as the words of a language, including single phrase and chunks of numerous words which convey a certain meaning, the way individual words do (Lessard, 2013,p. 2).

4- Fluency: It usually has to do with expressing oral language in a good pace without interruption (Pollard, 2008,p. 16).

5- Interaction: It is a collaborative exchange of thoughts, feelings, or ideas between two or more people, resulting in a reciprocal effect on each other (Brown, 2007,p.212). Many studies and researches showed that 


\section{Heba M. Mohamed, PhD}

speaking skills lead to the development of language proficiency and should be given due care (Torky, 2006). Speaking skill materials, speaking tests and teaching methodology should be given more attention in curriculum (Hamad, 2013; Mohamed, 2013).

Al-Nakhalah (2016) also revealed some difficulties facing students in speaking English such as fear of mistake, shyness; anxiety and lack of confidence. To shed light on the importance of the affective domain, Bergil (2016) concluded that the levels of Students' willingness to communicate have diverse effects on their overall speaking skills. To conclude, teaching English speaking skill to Arab EFL learners has always been an exacting task for Arab teachers of English because it is considered a foreign language, i.e. not widely spoken or used in everyday interactions. For such a reason, Arab teachers of English are required to persistently use new teaching strategies.

To solve the problems of speaking skills in the classrooms (AlSobhi \& Preece, 2018,p.1). Adopting suitable teaching methods and designing suitable teaching materials are among the major concerns of language teachers around the world. Although many teachers are eager to find the 'best' or most effective ways of teaching, there are no easy answers, given the wide range of sociopolitical contexts in which teaching takes place.

\section{Review of literature}

This section is divided into three parts : ELT Dogme, speaking skills and self-efficacy.

\section{ELT Dogme}

\section{Concept of ELT Dogme}

Dogme is a communicative approach that is not based on course books and require conversation-driven communication in the classroom. The main objective of any foreign language teachers is to give learners new language items which they will communicate. Therefore dogme can generate the salient language in the classroom and help teachers respond to learners' needs. According to dogme approach, neither the teacher nor the course book can decide which language items should be taught but the learners themselves. Meddings and Thornbury (2009) state that through dogme, teachers can reflect more on their classroom teaching. Also, they give learners an opportunity to analyze and acquire language through real conversations.

The philosophy of dogme teaching was named after dogme 95 film movement which was initiated by Larsen Trier whose aim was to cleanse cinema of sophisticated techniques and restore to its original format, foregrounding the story and the inner life of characters and avoiding sophisticated techniques.In the English classroom, Dogme call for 
Using Dogme in ELT to develop student teachers' Speaking skills and their

self-efficacy

teaching without course books and depends on communication among learners and teachers. Thornbury (2000) argued that the world of English language teaching was full of a large number of resources as there was no time left for real communication.

Dogme has the merits of generating the necessary language in the classroom and helping the teacher to respond to learners' needs. The learners themselves who decide which language should be taught, not the teacher or any course book. According to Thornbury (2009), teachers can reflect more on the process of teaching itself and give learners an opportunity to acquire language through real conversations.

\section{Principles of Dogme}

Meddings and Thornbury (2009) stated that the principles of Dogme ELT represent in :

1. There should be constant interactivity among learners and between teachers and learners.

2. As student create their own content, they will be engaged to the education process.

3. Learning is conversational and social.

4. The teacher and learners co-construct their knowledge.

5. Out of the learners' communicative needs, language and grammar can be learnt.

6. The teacher directs learners' attention to emergent language.

7. Learners select their content suitable for their beliefs and knowledge.

8. The classroom is free from published teaching materials which make both of students and teachers empowered.

9. All materials used a long the lesson are stick to the learners' needs.

10.Both teachers and learners will use published materials critically. Meddings (2003) determined the following scales of depth for a Dogme lesson:

1. Punk Dogme which focuses on live and local things rather than course books or handouts.

2. Talk Dogme which focuses on increasing interactivity in classrooms.

3. Deep Dogme that focuses on recording what has happened $n$ the lesson between teachers and students.

4. Full Dogme which encour ages the learners to bring in their own materials with them. No- body will know what the lesson will nbe about. The role of the teacher is to manage interaction and monitor the language. 
5. Dream Dogme which means the existence of language schools where learners organize themselves into classes that are based on their interests.

\section{Stages of a Dogme lesson}

1. Setting up a stage in which the teacher gives some kinds of stimuli to learners such as the dictation of a small text, a question or a picture.

2. Let it run a stage in which the learners are interacting with the teacher and among themselves and the teacher takes notes of emergent language.

3. Round it off stage in which the teacher focuses on the emergent language he noted in the previous stage.

Dogme is not ignoring planning but encouraging teachers to reflect upon the lesson in order to focus on the emergent language .Occasional Dogme classes can lead to diversity of the teacher's performance in the classroom and make learning more targeted and engaging.

\section{Effectiveness of Dogme ELT}

Dogme ELT has been studied either qualitatively or quantitatively . In a qualitative study, Sketchley (2011) carried out a study to recognize the difference between the opinions of both of teachers and students towards Dogme. Data was collected from fifteen teachers and students through questionnaires. Results showed that some of the study participants believed in the incorporation of Dogme ELT in their lessons while others preferred materials based lessons. Worth (2012) studied the opinions of nine Japanese learners on Dogme ELT and course book based lessons. The data collection instruments represent in open-ended questionnaires, group discussions and interviews with three students. The results of the study represent in that there is a strong association between the course book and test preparation. Also they prefer the Dogme ELT lessons to the course book based lessons.

Abdullah (2017) carried out a study to know what English as foreign language teachers (EFL) and their students think about Dogme ELT (English Language Teaching). Three university EFL teachers and thirty eight students participated in the study. The principles of Dogme ELT were introduced to teachers through relevant articles, activities of sample lessons. They were required to present a lesson in line with the principles of Dogme ELT. After that surveys were completed by both teachers and students to show their opinions concerning Dogme ELT. The results were positive, and it was suggested that Dogme ELT should be integrated to the mainstream EFL programs.

Further, qualitative studies have been carried out such as (Xerri,2012; Brydndal,2014) carried out studies to investigate the use of 
Using Dogme in ELT to develop student teachers' Speaking skills and their

\section{self-efficacy}

Dogme ELT and developed Dogme lessons once a month during an academic year. They recorded the positive and negative aspects of each lesson in a journal. In addition, they obtained information from students' feedback and unstructured interviews. The results of those studies showed that Dogme can be used even in exam preparation and is useful because of the interaction and the language emerging in the classroom. Also they shed a light on the learner centered and materials light principles that empower the teacher.

Bryndal (2014) designed lessons based on Dogme ELT. The main objective of the lesson was to introduce and practice vocabulary related to household problems. The results of this study showed that students liked the lesson more than the traditional one. It was successful with preintermediate class, but doesn't suit the lower level students. Also it can be successful with the experienced teachers, but the novice ones can not use it.

\section{Speaking skill}

'Brown (2000) mentioned that speaking is the most difficult skills for students because of the following features of the oral discourse:

a. Contractions, vowel reductions and elision.

b. Use of idioms and slang.

c. Intonation, rhythm and stress.

d. The need to interact with others.

Speaking is an activity that requires the integration of many factors that are combined to make speaking a second or foreign language a formidable task for language learners. For many people, it is considered the focal skills.( Nunan, 2001).Lindsay and Knight (2006,p.58)ensured that speaking is needed for many reasons to be able to deal with others to respond to others or express feelings.

Harmer(2007,p.46) mentioned that human communication is complex. People need communication when they want to say something or give information. When speaking, words and phrases are constructed, pitch change, intonation and stress are used to cover different meanings. In face to face interaction, the speaker can use facial expressions, gestures and body language to help convey the message.

Nunan (2001) claim that many English teachers mentioned that the best way to acquire speaking skills is through interaction. This aim can be achieved by communicative language teaching and collaborative learning. Communicative language teaching focuses on real-life situations that require communication. By using this method in ESL classes, this can 


\section{Heba M. Mohamed, PhD}

give opportunities for the students to communicate with their peers in the target language.

\section{Speaking self- efficacy}

Pajares(2002,p.5) asserted that much empirical evidences proved that self-efficacy beliefs affect every aspect of people' lives whoever they are whatever their personality. The reviewed literature suggest that selfefficacy as a concept has a productive and explanatory power. An essential problem with self-efficacy is not linked with the concept itself but the term as it is used widely with a shallow appreciation of its complexity.

As the main focus of modern language learning theories has been the obtainment of communicative competence which is considered as an acquisition as a collaborative social process ( Warschauer and Kern,2000; Omaggio-Hadley,2001) .Gursoy and Karaca (2018) carried out a study that aimed to analyze the effect of speaking anxiety on speaking selfefficacy of younger and older child learners. Both of the qualitative as well as quantitative methods used in the study. One hundred and fifty students from $5^{\text {th }}$ and $8^{\text {th }}$ grades participated in the study scales for speaking self- efficacy and anxiety were used as well as the use of interviews as the instruments of the study. The findings showed a strong negative correlation between speaking efficiency and speaking anxiety. Surveying 250 university students in Turkey, Tilfarlioglu and Ciftici(2011)revealed similar results. Similarily, Basaran and Cabarogli(2014)stated that foreign language teachers observed that learners who have low proficiency in English have less self-efficacy to learn a foreign language properly. As a productive skill, speaking challenges language learners' ability to perform a task. Communication is the ability to interact and speak with other people. Shumin (2002) asserts that speaking a foreign language is challenging as effective oral communication requires the ability to use the language in social interaction appropriately .

According to Shumin ( 2002), some factors such as attitude, selfesteem , motivation, anxiety and self-efficacy can affect EFL learners' oral communication. Gursoy and Karaca (2018) claimed that self-efficacy is the learners' abilities to communicate in the target language appropriately. Taipjutorus, Hansen, and Brown (2012) ensured that learners' self- efficacy can be specific to the context of a situation but can be generalized.

Kim and Lorshbach (2005) carried out a study on pre-university ESL learners to investigate the relation between self-efficacy and speaking. The results showed that the students presented high levels of self-efficacy in relation to speaking skills.Cubukcu(2008) indicated that 
Using Dogme in ELT to develop student teachers' Speaking skills and their

self-efficacy

high self-efficacy beliefs direct the learners to engage in class activities more, so the learners can increase their academic achievement. According to Tilfarlioglu and Cinkara (2009), university students with high selfefficacy are more motivated and active in speaking activities. Also a study by Genc, Kulusakh and Aydin (2016) stated that language learners have high self-efficacy for reading and speaking skills than for listening and writing skills.

\section{The problem}

In spite of the great importance of speaking as it is the basic requirement of oral communication, it has been proven too be ignored in language classes. The researcher has divided the research problem into the following:

\section{The pilot study}

The pilot study was conducted to identify student teachers' level in speaking skill. The pilot study sample consisted of 30 students in the first year English majors, faculty of Education, Beni Suef University. The researcher administered an English speaking test. (Appendix 1). The results of this test showed that they have an observable lack of speaking skills, especially in pronunciation, grammar, vocabulary, fluency and interaction. $75 \%$ of students have such problems in pronouncing sounds, following intonation and stress patterns that their poor pronunciation obscures communication and prevents them from making their meaning known. $70 \%$ of students do not produce appropriate morphological and syntactical patterns in a given speech situation. $80 \%$ of students have so many problems with vocabulary that they do not have certain words available to use in speaking situations. For fluency, $85 \%$ of students have difficulty producing fluent speech simply because they lack the vocabulary or grammar to express what they want to express. $75 \%$ of students have difficulties in their interactive competence with others.

The problem of the study has also been reinforced by previous studies in the Egyptian context such as the studies of Ghanem (1983), Al Khuli (2000), Torky (2006) and Aly, et al (2013) which confirmed that Egyptian secondary school student's EFL speaking skills are neglected and highlighted the urgent need for effective teaching strategies to develop speaking skills.

\section{Statement of the problem}

Taking into account the aforementioned observations, interviews, the diagnostic test and previous related studies, it is concluded that student teachers have difficulties in their speaking. Therefore, the current study is 
an attempt to design activities based on dogme in order to develop speaking skills and to enhance self- efficacy.

\section{Questions}

To solve the problem of this study, the main research question is formulated as follows:

What is the effect of dogma on developing first year English majors students' speaking skills and their self-efficacy?

There are a number of emanating sub-questions as follows:

1- What is the effect of using dogme on developing the speaking skills of first year English majors at the faculty of Education?

2- What is the effect of using dogme on developing speaking self efficacy of first year English majors at the faculty of Education?

\section{Objectives}

The current research attempts to achieve the following objectives:

- Determining the effect of dogme on developing first year English majors' speaking skills.

- Investigating the effect of dogme on developing English majors' speaking self- efficacy.

\section{Hypotheses of the study}

To answer the research questions, a number of research hypotheses are formulated as follows:

1- There is a statistically significant difference between the mean scores of the study group students exposed to Dogme in the pre and post administration of the pre-post speaking test in favor of the post administration.

2. There is a statistically significant difference between the mean scores of the study group students exposed to dogme in the pre and post administration of the speaking self-efficacy scale in favor of the post administration.

\section{Variables of the study:}

Independent variable: This refers to the treatment implemented in this study (dogme based activities implemented with the study group).

Dependent Variable: This refers to the study group students' performance in speaking skills with their sub-skills in addition to their speaking self- efficacy .

\section{Significance of the study}

The importance of this study can be due to the following reasons:

1- This study may be considered as a pioneering study in this field and hence it inspires other researchers with new research fields or areas since 
Using Dogme in ELT to develop student teachers' Speaking skills and their

self-efficacy

few previous studies have conducted dogme for the freshmen at the faculty of education, English majors .

2- The findings of this study will hopefully provide specialists, course designers and stakeholders with empirical evidence and more insights concerning the potential of using a virtual learning environment based on the web-based software system for secondary school students in English language learning. The findings of this study will redound to the benefit of society since there is a greater demand for graduates with fluent and accurate English background.

4- The study provides a list of speaking skills necessary for first year students English majors, Faculty of education to be taken into consideration in planning and designing speaking activities suitable for those students as well as in evaluating their speaking performance.

\section{Participants}

The participants of this research include 44 freshmen at the faculty of education, Beni Suef University, English majors. They will be included in the study group.

\section{Instruments}

1. A Pre-post speaking test which measures the following speaking skills:

a. Using intelligible pronunciation.

b. Following grammatical rules accurately.

c. Using relevant, adequate and appropriate vocabulary.

d. Structuring discourse coherently and cohesively.

e. Managing conversation and interacting effectively.

f. Uttering discourse fluently.

\section{Speaking Self-efficacy scale}

\section{Validity and Reliability of the research instruments}

The validity of the speaking test as well as the self-efficacy scale were assured throw judging it by the jury members $(\mathrm{N}=5)$. The reliability of the speaking test was measured by alpha technique. It was 0.82 for the speaking test while 0.88 for the spaeking selfefficacy. They are significant at 0.01 . 


\section{Heba M. Mohamed, PhD}

\section{Manipulated Materials \\ Speaking skills checklist}

The researcher developed a checklist of speaking skills checklist and presented it to the jury members who modified it to be in its final version (Appendix 2).

\section{ELT Dogme}

According to the instructions of Dogme, participants have the right to select the studied topics. In this research, they selected to study conversations related to the following topics:

1. First day at university.

2. Interview for new work.

3. First day at work

4. Meeting people for first time.

5. At an airport

6. At a hotel

7. At a café

8. A t a street

9. At a restaurant

10.At a police station

The instructor asked the participants to try to create conversations related to each topic at a time, and she helped them in acting those conversations. The treatment lasted for ten sessions (One session a week). Each session lasted for two hours, so the whole treatment lasted for twenty hours in the first semester in 2018/2019.

\section{Design}

The study adopted the pre- post treatment using one group design $(n=44)$.

\section{Delimitations}

1- First year, English majors, Beni Suef university.

2- Speaking skills.

a. Using intelligible pronunciation.

b. Following grammatical rules accurately.

c. Using relevant, adequate and appropriate vocabulary.

d. Structuring discourse coherently and cohesively.

e. Managing conversation and interacting effectively.

f. Uttering discourse fluently. 
Using Dogme in ELT to develop student teachers' Speaking skills and their

self-efficacy

\section{Definitions of terms:}

Speaking skills

It is a productive and active skill that helps students produce units of meanings in phrases and clauses. It is an interactive process of constructing meaning that involves producing, receiving and processing information. (Dash and Dash,2007;GruberMiller,2006;Brown,1994;Burns and Joyce,1997; Butterfield,2010).

Bygate (2003) defined speaking as a productive skill in which students pronounce words and sentences for specific purposes to give certain messages using the suitable grammatical rules, vocabulary and score of formality with the atmosphere of confidence and comfort.

\section{Self-efficacy}

their abilities to produce designated levels of performance that exercise influence over events that affect their lives. The beliefs of self-efficacy can determine how people feel, think, behave and motivate. Themselves.( Bandura, 1997).

\section{Speaking Self -efficiency}

Gursoy and Karaca (2018) defined it as the learners' abilities to communicate in the target language appropriately: feeling confident and competent to struggle while using the target language.

\section{ELT Dogme}

Meddlings and Thorunbury(2009, p.21) pointed out that "Dogme" is a learner-centered approach of teaching that enables conversational communication between learners and the teacher without using preplanned lessons or published materials.

\section{Results}

The number of the participants were forty four students $(n=44)$, The mean scores of the participants in the pre administration of the speaking test was 11.25 while the mean scores in the post administration of the same test was 18.39. The standard deviation of the pre administration was 2.94 while it was 2.34 in the post administration of the same test. The researcher used " $t$ " test for paired samples .It was "21.36". The Eta squared effect size was "0.91". 
Table (1)

Means, standard deviations, " $t$ " test for paired samples and Eta squared effect size in pre and post administrations of the speaking test.

$\begin{array}{cccccc} & \text { NO. } & \text { Mean } & \begin{array}{c}\text { Std- } \\ \text { Deviation }\end{array} & \text { t } & \begin{array}{c}\text { Effect } \\ \text { size }\end{array} \\ \text { Pre } & 44 & 11.25 & 2.94 & 21.36 & 0.91 \\ \text { Post } & 44 & 18.39 & 2.34 & & \end{array}$

The researcher used "t" test for paired sample to check if there is a difference in the mean scores of the participants in the pre and post administration of Dogme based course. As it is clear in table (1), the " t" test score was 21.36 which is significant at 0.01 which means that the first hypothesis was proven to be true. Further the effect size was 0.91 which is strong that supports the first result. The following diagram represents the previous results:

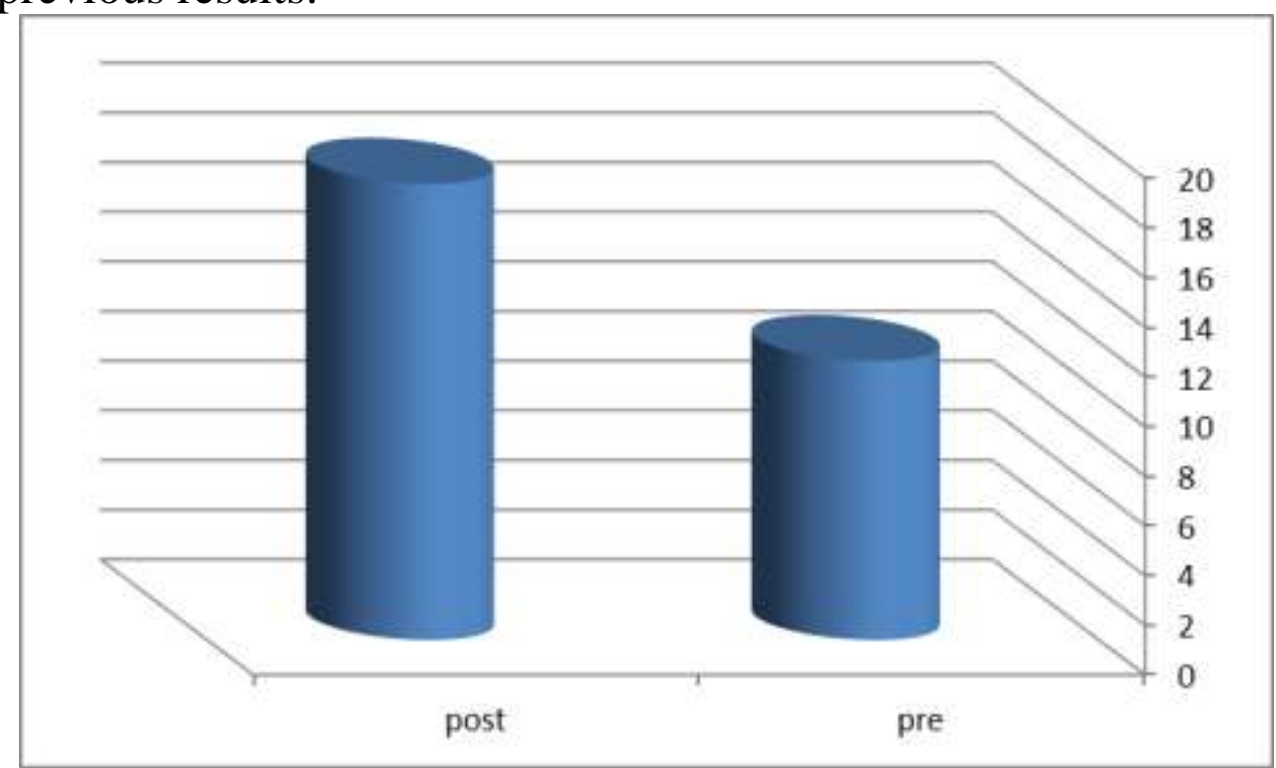

Figure (1)

Pre and post administrations of the speaking test

The mean score of the participants in the pre administration of the self efficacy scale was 25.34 while the mean scores in the post administration of the same scale was 43.98. The standard deviation of the pre administration was 5.75 while it was 4.89 in the post administration 
Using Dogme in ELT to develop student teachers' Speaking skills and their self-efficacy

of the same scale. The "t" test score was 26.75 , and the effect size was "0.94" as it is shown in the following table:

Table (2)

Means, standard deviations, " $t$ " test for paired samples and Eta squared effect size in pre and post administrations of the Self- efficacy scale

$\begin{array}{cccccc} & \text { No. } & \text { Mean } & \begin{array}{c}\text { Std- } \\ \text { Deviation }\end{array} & \text { t } & \begin{array}{c}\text { Effect } \\ \text { size }\end{array} \\ \text { Pre } & 44 & 25.34 & 5.75 & 26.75 & 0.94 \\ \text { Post } & 44 & 43.98 . & 4.89 & & \end{array}$

The researcher used " $\mathrm{t}$ " test for paired sample to check if there is a difference in the mean scores of the participants in the pre and post administration of Dogme based course. As it is clear in table (2), the " $t$ " test score was 26.75 which is significant at 0.01 which means that the second hypothesis was proven to be true. Further the effect size was 0.94 which is strong that supports the second result. The following diagram represents the previous results:

The following diagram represents the previous results

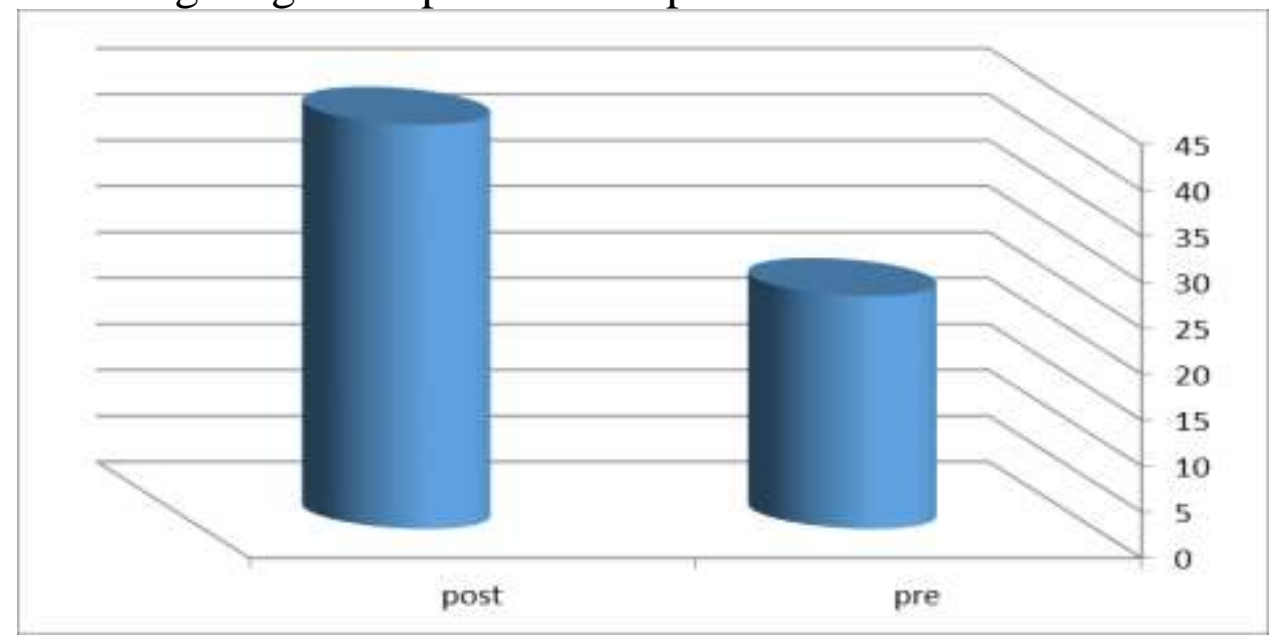

Figure (2)

Pre and post administrations of the self-efficacy scale 
Based on the abovementioned results, the following findings can be stated:

1.This research indicated that the speaking skills for the first year English majors, Faculty of Education, Beni Suef University were greatly enhanced due to the use of Dogme ELT based course.

2. Speaking Self- efficacy of first year English majors, Faculty of Education, Beni Suef University were greatly enhanced due to the use of Dogme ELT based course.

\section{Discussion of Implications}

Analysis of the data suggests that the use of the Dogme ELT is effective for developing speaking skills as well as the self- efficacy of freshmen at the faculty of education in Beni Suef English majors. The data showed that students' scores improved throughout the five-week study, supporting the conclusion that both of speaking skills and self efficacy were developed. The hypotheses that the Dogme ELT created the speaking skills as well as the self -efficacy of the research participants was proven to be true. Additionally; the qualitative data suggests that more research should be done on the social aspect of the Dogme ELT use on the classroom environment. It is important to explore how Dogme ELT may improve the social skills in ELL's and the entire social climate of the classroom. It is theorized from the evidence in this research that using the Dogme may improve instruction, instructional dialogue, and continued development of speaking skills and self -efficacy for all students. The results of the current research may be due to the free nature of Dogme ELT which suits the type of life those days and the desire of most students. This research is based on students' own desires in selecting the topics of the course that break the traditional mode of learning in the school and inside the classroom borders. The researcher felt the progress of the participants step by step as there was a gradual progress. By the end of the research the participants were expressing themselves very well and there was an observable change in their speaking skills as well as their self-efficacy.

Further, working in groups, participants showed enthusiasm and motivation in producing English sentences and practice speaking with each other. The four weeks of practice have made the students more confident to speak English. 
Using Dogme in ELT to develop student teachers' Speaking skills and their

self-efficacy

\section{Conclusion}

With reference to the results of this study, the following points were concluded:

1- The present study provided an evidence to the effectiveness of using Dogme ELT based course in enhancing the speaking skills of the participants of the research. This result adds to the validity of other study investigating similar aspect such as that of Xerri, 2012 and Bryndal, 2014.

2- The present study provided an evidence to the effectiveness of using using Dogme ELT based course in enhancing the self efficacy of the participants of the research. Recommendations of the study

Based on the results and conclusions of this study, the following recommendations are suggested:

1- Course designers should bear in mind the free style of Dogme ELT in developing courses such as conversation to develop the speaking skills of students more efficiently.

2- EFL instructors need to plan activities that motivate students to use new learning strategies and methods and provide practice opportunities.

3- Institutions' administration should be open enough to accept the free styles in developing courses..

4- The culture of free styles in developing courses should spread in the learning field.

5- However, it is a hugely advantageous style of teaching that will help students to truly learn and it is worth implementing at every school.

\section{Limitations}

The current research met some challenges such as the traditional nature of the Egyptian courses and the traditional type of thinking. Especially in the Egyptian EFL contents where there are many factors that may hinder the application of Dogme ELT such as the traditionalist expectations about 


\section{Heba M. Mohamed, PhD}

course delivery, exam stresses and large class sizes. Further this mode of teaching requires a special type of instructors, administration as well as students. It needs open minded instructors, who accept the different opinions of students. Also it requires a special type of administration who accept change. As for students, they should express themselves and select the most appropriate topics they need to learn. In addition of the open mindedness of the instructor himself/herself, it needs an expert one who can manage the class well to gain the fruits of learning effectively

\section{Suggestions for further research}

The following points are recommended to be considered for further research:

1- This study can be replicated at a different level of education and with larger participants.

2- Test the effectiveness of ELT Dogma in developing the different language skills.

3- Test the effectiveness of Dogme ELT in developing self confidence of students.

4- Test the effectiveness of Dogme ELT in developing students' engagement of students. 
Using Dogme in ELT to develop student teachers' Speaking skills and their

self-efficacy

\section{References}

Abdullah,C.(2017). Dogme ELT: What do teachers and students think? International Journal of Research Studies in language learning, 6(2),pp.33-44.

Aly,M;iyyab,E;Abdel-Haq,E. (2013). Using a multimedia based program for developing student teachers' EFL speaking fluency skills, Journal of Benha university , 25(10),pp.1-28.

AL Khuli, S. (2000). The Effect of Using some Questioning Strategies in Teaching English on Developing the First Year Secondary School Students Speaking Skills. Unpublished M.A. Thesis, Faculty of Education, Ain Shams University.

Al-Nakhalah, A. (2016): Problems and Difficulties of Speaking That Encounter English Language Students at Al Quds Open University. International Journal of Humanities and Social Science Invention, Vol. (5), Issue (12), pp. (96-101).

Al-Sobhi, B. \& Preece, A. (2018).Teaching English Speaking Skills to the Arab Students in the Saudi School in Kuala Lumpur: Problems and Solutions. International Journal of Education \& Literacy Studies, Vol. (6), No. (1), pp. (1-11).

Bandura, A.(1997). Self-efficacy : The exercise of control. New york : Freeman Basaran, S. \& Cabaroglu,N. (2014). The effect of language learning podcasts on English self-efficacy. International Journal of language of language Academy, 2(2),pp. 48-69.

Bergil, A. (2016): The Influence of Willingness to Communicate on Overall Speaking Skills among EFL Learners. International Conference on Teaching and Learning English as an Additional Language, GlobELT: Procedia - Social and Behavioral Sciences, Vol. (232), PP. $(177-187)$.

Brown, D. (2007): Principles of Language Learning and Teaching. USA: Pearson Longman.

Brown, H.(2000). Principles of language learning and teaching, 4th ed. New york: Longman.

Brown, H..(1994).Teaching by principles : an interactive approach to language pedagogy. Englewood Cliffs, NJ: Pretice Hall Regents

Brydndal, M.(2014). Dogme ELT. Developing Teachers. Retrieved from http://www.developing

teachers.com/articles_tchtraining/dogme1_malgorzata.html

Burns, A.and Joyce,H.(1997). Focus on speaking. Sydney: National center for English language teaching and research.

Butterfield, J.(2010). Verbal communication. Boston: Course technology. Bygate, M.(2003). Speaking. (10th ed). Newyork: Oxford University Press. 


\section{Heba M. Mohamed, PhD}

Cubukcu, F. (2008). A study on the correlation between self-efficacy and foreign language learning anxiety. Journal of Theory and Practice in Education, 4(1),pp.148-158.

Dash,N. \&Dash,M. (2007).Teaching English as an additional language. New Dely: Atlantic Publishers and Distributers (p)LTD.

Genc,G., Kulusakli, E. \& Aydin, S. (2016). Exploring EFL learners' perceived self-efficacy and beliefs on English language learning. Australian Journal of Teacher Education, 41(2), pp. 53-68.

Ghanem, S. (1983): The Effect of Developing Verbal Interaction Pattern of Teaching English on the Speaking Skill of the Secondary Students. Unpublished PhD. Dissertation, Faculty of Education, Ain Shams University.

Gruber-Miller, J.(2006). When Dead Tongues Speak : Teaching Beginning Greek and Latin. New York: Oxford University Press, INC.

Gursoy,E\&Karaca,N.(2018).The effect of speaking anxiety on speaking selfefficacy of children in a FLL context. International Journal of Language Academy, 6(3),pp.194-210.

Hamad, M. (2013): Factors Negatively Affect Speaking Skills at Saudi Colleges for Girls in the South. English Language Teaching, Vol. (6), No. (12), pp. (87-97).

Harmer. J.(2007). The practice of English language teaching ,4th ed., London: Longman.

Iman, J. (2017): Debate Instruction in EFL Classroom: Impacts on the Critical Thinking and Speaking Skill. International Journal of Instruction, Vol. (10), No. (4), pp. (87-108).Retrieved on June 25, 2018, from: https://doi.org/10.12973/iji.2017.1046a

Kim,J \& Lorsbach,A.(2005).Writing self-efficacy in young children : Issues for the early grade environments. Learning Environments Research,8, pp.157-175.

Kline, J.. (1998): Speaking Effectively a Guide for Air Force Speakers. Alabama:congress books.

Lessard, M. (2013): teaching vocabulary. Virginia USA: Editorial, Thomas S.C.Farrell.

Lindsay, C., \& Knight, P. (2006) : Learning and Teaching English: A Course for teachers. Oxford University Press.

Litualy, S. (2016): Integrative Teaching Techniques and Improvement of German Speaking Learning Skills. Journal of Education and Practice, Vol. (7), No. (9), pp. (56-61).

Meddlings, L. \& Thornbury,S.(2009). Teaching Unplugged : Dogme in English language teaching. Peaslake : Delta publishing, p.12.

Meddlings,L.(2003).Dogme still able to Divide ELT. Retrieved from http://www.theguardian.com/education/2019/Jan/18/tefl./ukemeddin gs. 
Using Dogme in ELT to develop student teachers' Speaking skills and their

\section{self-efficacy}

Mohamed, M. (2013): Problems of Speaking English Language Among University Red Sea University Students. Unpublished Ph.D. Dissertation, Faculty of Education: Red Sea University, Egypt.

Natale,K.\&Lubniewski,K.(2018).Use of Communication and Technology among Educational Professionals and Families. International Electronic Journal of Elementary Education, 10(3),pp.377-384.

Nunan, D. (2001). Designing tasks for the communicative classroom. Cambridge : CUP.

Nunan, D. (ed.) (2003). Practical English Language Teaching. New York: McGraw-Hill.

Omaggio-Hadley,Ac(2001). Teaching language in context : proficiency oriented Instruction. Heinle and Heinle , Boston, MA

Pajares,F.(2002).Overview of social cognitive theory and self-efficacy. Retrieved in December 2018 from www.uky.edu/eush2/pajares/etf.html

Pollard, L. (2008). Teaching English a book to help you through your first two year in teaching. London: Longman, second edition.

Richards, J. \& Renandya, W. (2002): Methodology in language teaching: An anthology of current practice. Cambridge: Cambridge University Press.

Shumin, K. (2002). Factors to consider : Developing adult EFL students' speaking abilities. In J.C.Richards, \& W.A. Renandya (Eds.), Methodology in language teaching, pp. 204-211.Cambridge : Cambridge university press.

Sketchley, M.(2011). An investigation into teacher and student attitudes of the key tenets of Dogme ELT.Material thesis. Retrieved from http://www.scribd.com/doc/836841171/Dogme-ELT-DissertationFinal-version.

Soureshjani, K. (2013): A study on the effect of self-regulation and the degree of willingness to communicate on oral presentation performance of EFL learners. International Journal of Language Learning and Applied Linguistics World, Vol. (4),No. (4), pp. (166-177).

Taipjutorus, W., Hansen, S., \& Brown, M. (2012). Investigating a relationship between learner control and self- efficacy in an online learning environment. Journal of open, Flexible and Distance learning, 16(1), pp. 56-59.

Thornbury, S. (2000).A Dogme for EFL.IATEFL Issue 153.February/March.Retrieved from http://nebula.wsing.com/fa3dc70521483b645f4b932209f.9db17?

Tilfarlioglu, F. \& Ciftci, F. (2011). Supporting self-efficacy and learner autonomy in relation to academic success in EFL classrooms ( A case study). Theory and practice in language studies, 1(10),pp. 12841294. 


\section{Heba M. Mohamed, PhD}

Tilfarlioglu, F. \& Cinkara, E. (2009). Self-efficacy in EFL: Differences among proficiency groups and relationship with success. Novitas-Royal, 3(2), pp.129-142.

Torky, S. (2006): The Effectiveness of a Task- Based Instruction program in Developing the English Language Speaking Skills of Secondary Stage Students.Unpublished Ph.D. dissertation, Women's college: Ain Shams University, Egypt.

Warschauer,M and Kern,R.(2000).Theory and practice of network-based language teaching, In M Warschauer and R Kerns(Eds.), Networkbased language teaching conepts and practice, Cambridge University Press, Cambridge , England, pp.1-19.

Williams, J. (2008):Teacher's Grammar Book. . Mahwah New Jersy: Soka University.

Worth, A. (2012). A Dogme based approach from the learners' perceptive,The Journal of Kanda University of International Studies, 24(77-99).

Xerri, D. (2012). Experimenting with Dogme in a mainstream ESL Context, English Language Teaching, 5(9), 59-65. Available online at http://dx.doi.org/10.5539/elt.v5np59. 